\title{
PUBLIC UTILITY REGULATION BY LOS ANGELES
}

\author{
By Charles K. Mohler, \\ Chief Engineer Railway Department, Board of Public Utilities, \\ Los Angeles, Cal.
}

California cities have enjoyed a large measure of home rule granted by the state constitution. In this respect they are more fortunate than most American cities. A still greater latitude for the larger cities to work out their local problems is desirable. The city of Los Angeles has generally made good use of the privileges it enjoys in this respect. It has, however, in a measure fallen short of the best requirements in creating a strong and well equipped department for regulating public utilities.

Up to the time the board of public utilities was created by charter amendment the rate-making and regulating power was vested exclusively in the city council.

\section{Board Created by Referendum}

The Municipal League of Los Angeles started the movement in 1907 to secure a board of public utilities. After two years of agitation the city attorney was instructed by the city council, then about to retire, to prepare an ordinance to create a board. The city attorney's draft was rejected by the council and another substituted instead. This in turn did not meet with the approval of the Municipal League. The league prepared a substitute ordinance which was passed as an initiative measure by popular vote at the ensuing election by 16,626 for and 9,696 against.

Thus was first created a department of public utilities. On December 20,1909, the mayor appointed the three commissioners to make up the board. The board was organized on December 27. As constituted under the provisions of this ordinance the rate-making powers of the board were limited to that given in the following language: "To recommend to the City Council . . . . a schedule of charges for the services specified 


\section{Board Created by Charter Amendment}

On March 25, 1911, fourteen city charter amendments were approved, article 15 of which provided for a department of public utilities. Previous to this charter amendment, as indicated above, the board could only recommend to the council the rates to be charged.

In preparing the draft of the charter amendment creating a board, the framers proposed to give it full power to fix rates subject to review only by the courts. The council refused absolutely to submit the amendment carrying that power for the board. They insisted that rate making was a prerogative that should not be given up by the council as it required their guardianship to stand between the people and the power of the corporations.

Three commissioners constitute the board, with a term of office of four years. They are appointed by the mayor subject to confirmation by the council. Up to March 1, 1912, all commissioners served without pay. Since that time the president has been allowed a salary of $\$ 3,600$ a year and is expected to devote his entire time to the work of the board. The commissioners are subject to the recall as are all city officials.

\section{Powers and Duties of the Board}

The city charter provides that the powers and duties of the board of public utilities shall be as follows:

To make at such times as may be prescribed by ordinance a thorough investigation into the affajrs of all persons, firms or corporations operating or maintaining water, electric lighting, power, gas or telephone systems, or street railways, or interurban railroads, or other public service utilities, in the city of Los Angeles. Such data shall include a valuation, a detailed statement of gross and net earnings, expenses, capitalization and indebtedness thereof, and such other matters as the board may deem proper, and also such facts and figures as may be obtainable regarding the operation and maintenance of similar systems and utilities in other municipalities.

To fix, subject to approval, change or modification by the council, the rates to be charged and collected for the service mentioned, for a period not less than one year, nor for a longer period than three years. 
Any person interested in or affected by the rates specified in any such resolution may file objections thereto. The council may, upon any such petition, by a vote of two-thirds of its members, order a rehearing of the rates objected to, and shall have the power to finally fix such rates ${ }^{1}$ by approving, changing or modifying the same. The affirmative vote of two-thirds of the entire council shall be necessary.

To investigate complaints against the service or charges of any person, firm or corporation operating any public service utility in the city.

To superintend the inspection of all public utilities operated, maintained or furnished by persons, firms or corporations, as to their compliance with their franchises, and with the law and ordinances of the city regulating the manner of conducting their business, and their treatment of the public, and to recommend such legislation, or executive action based on such investigation, as in their judgment may be required.

To prepare and keep a detailed and indexed record of all public service franchises granted by the city that are now in existence, or that may hereafter be granted, showing the date, location, term thereof, and all other essential facts, and a similar record, so far as practicable, of all other public franchises exercised in the city of Los Angeles.

To pass on applications for franchises. Every application to the city council for a franchise for any public service or utility shall be referred to the board of public utilities for its recommendation. No franchise shall be advertised for sale or granted contrary to the recommendation of said board except upon a three-fourths vote of the entire council.

To make and enforce subject to ordinances adopted by the council, rules and regulations respecting the operation of all public utilities.

To require attendance of witnesses, production of books, records, papers at investigations, hearings, etc. Each member of the board is empowered to administer oaths.

1 Italics, the writer's. 


\section{Inadequacy of Powers}

The powers of the board are too limited and are not as well defined in the charter as they should be. While the council has the power to enlarge and better define these powers and duties, this has not as yet been done in a satisfactory manner. The charter provisions as above quoted in abstract show a conspicuous example of apparent distrust and lack of confidence in the ability and integrity of appointed officials. The work laid out for the board is not only limited, but is hedged about with checks and balances. As might be expected its work cannot be undertaken with the degree of confidence and assurance essential for constructive efficiency.

On account of inadequate power and lack of support from the council, the personnel of the board's commissioners has changed on an average of about once a year since its organization. These men have not been partisan spoilsmen but, with rare exceptions, have been men of unquestioned ability and integrity.

\section{Public Utility Concerns in Los Angeles}

The number of utility concerns giving service in Los Angeles are: three steam or "interstate" railroads; two electric (city and interurban) railroads; three incline railways; two express (interstate) companies; three electric light and power systems; four gas systems; three telephone systems; two telegraph systems; eighteen water service systems. In addition to the above the board has a measure of supervision over local express and delivery service, as well as taxicabs and automobiles for hire. Water, gas and electric meters are tested by the board. The gas inspection and testing are done under the direction of the board.

\section{Valuations Made of Utilities}

Of the above utilities the board has made more or less complete valuations for rate-making purposes of two telephone companies, sixteen water companies, four gas companies, and three electric light and power companies.

The valuation of the local street railway comprised of something over three hundred and sixty miles of single track, narrow gauge line, was undertaken a year ago with the double object in view of rate 
fixing and service requirements and a possible basis on which to base preliminary negotiations looking to the city's undertaking the purchase for municipal ownership and operation.

No valuation of the interurban system and its local lines within the city limits has been undertaken as this line is being appraised for the state railroad commission and it is expected the data required by the board will be available when that is completed.

\section{Rates Fixed}

Rates have been fixed for all gas, electric light and power, telephone and all of the water service concerns. In all cases but one the rates fixed by the board have been accepted by the utility service concerns. One water case has gone to court on the board's rates, and has not yet been decided. The company is now getting a rate higher than that fixed at the time by the board, and less than their old rates.

Where protests have been filed and the council has lowered the rates below those fixed by the board, all have been taken into court, except one of little importance, with the following results: In the telephone case, the city lost.

One water rate case is now pending in court. The court granted a temporary injunction and the company is now being allowed to charge the rates originally fixed by the board.

The extra expense in litigation, revaluation, etc., to the city in these cases lost has been about $\$ 16,000$ while the gain to the protestants bas been apparently nothing.

\section{Practical Results: Rates and Service}

The rates fixed by the board have in most cases been lower than those in effect prior to its organization. On the local street car system the fare is five cents with practically universal transfers over the system. On some of the local lines of the interurban system there are fares charged inside the city limits which are not considered entirely equitable. No reduction of street car fares has been undertaken by the board but some of the fares now in effect and the limited transfer situation will have to receive the attention of the board in the near future. Gas rates have been lowered from 80 cents to 70 cents for 1,000 cubic feet with an annual saving of a little 
over $\$ 400,000$ to consumers. There is a controversy on at the time of writing this article relating to fixing the rate for natural gas recently brought to the city, which may be a repetition of the telephone case above mentioned. The rate fixed by the board is 52 cents. The popular demand is for 30 cents per 1,000 cubic feet. Electric light and power rates have been lowered from an average of 9 cents to 6 cents for light and 5 cents for power per k.w.h. resulting in an annual saving to the consumers of from $\$ 400,000$ to $\$ 500,000$ per annum. Telephone rates have been equalized and for some classes of service slightly increased. As there are two systems the rates had already been cut by competition to little more than the cost of conducting the business. Water rates have been reduced in some cases. Water rates charged by private companies are high and in quite a number of cases poor service is rendered. The metered rate for private companies is in general from $\$ 1.25$ to $\$ 1.88$ for the first 1,000 cubic feet and 8 to 14 cents for each additional 100 cubic feet. The rate charged by the city is $\$ 0.75$ for the first 1,000 cubic feet and 7 cents for each 100 cubic feet additional.

The service rendered by the local street car system compares favorably with that of any other in the country.

The local service rendered by the system engaged largely in interurban and suburban business is not fully satisfactory on all lines on account of fares and transfer privileges. This system comprises about 1,000 miles of single track in Los Angeles and vicinity. The interurban service is generally good, but in many cases too much standing room is used. There are some matters in connection with this service that will probably have to occupy the attention of both the state railroad commission and the board jointly.

The gas service is generally good. Natural gas has been piped to the city, a distance of 111 miles. For nearly a year past a mixture of natural and artificial gas has been furnished. The mixture is from 40 to 50 per cent natural gas, giving about 150 b.t.u. heat units over the artificial, which must not be below 600 per cubic foot. Under the supervision of the board the number of heat units for artificial gas has been raised from 560 to 622 b.t.u. for the daily average.

The electric light and power are generally reliable and well maintained. The city buys current for street lighting. Telephone service is generally reliable and fairly well maintained. The service from the private water companies is in many cases thoroughly unsat- 
isfactory. In some the supply is insufficient, unreliable and hardly fit for use. No permanent relief can be expected in many cases until the city's service is established. Many of these enterprises had their origin in projects for selling real estate. They are practically all operating without a city franchise and the only thing that holds them to their obligation to furnish water is the state law which does not allow the discontinuance of water service, when it has once been established, unless the user voluntarily gives a release.

\section{Complaints}

The board receives a large number of complaints on service, bills rendered, treatment accorded the public, etc. As many of these as possible are handled in an informal way by the employees of the department. Generally the rule is enforced that all complaints to receive attention must be presented in writing. The large majority of all complaints are adjusted without formal action and orders from the board. In most cases the utility concerns have shown a willingness to comply with requests from the board to make reasonable changes and corrections in service, bills of charges, etc. There are still questions not well settled that are open to possible controversy affecting the powers of the board and the obligations of the utility concerns.

One of the most important functions of the board is to bring about wherever possible (and it is their earnest endeavor so to do), a better understanding and a more friendly feeling between the patrons and the utilities furnishing service. Complaints are of two kinds, those having a real and those having an imaginary basis. Both should receive impartial consideration. Imaginary grievances are real to the aggrieved party until they are shown to be groundless. Wherever complaints are well founded, they are investigated and the necessary remedies or corrections secured.

\section{City and State Control}

The relationship between the city and the state on some matters of jurisdiction where interstate and interurban railroads are concerned has not been finally passed on in all cases. The relations of the board with the state railroad commission are and have been friendly and a spirit of coöperation exists. 
The "home rule" situation in California is perhaps unique. The state constitution as amended in 1911 provides that counties, cities and incorporated towns may vote to retain their powers of control and regulation over public utilities. After voting to retain control they can vote themselves under the state railroad commission control. After voting themselves under that control they can vote themselves out again. As to how many times this can be repeated the constitution fails to state.

A constitutional amendment to be voted on next fall, if adopted, will put rate-making in the hands of the state railroad commission. A county, city and county, or incorporated city or town may vote to retain local control and regulation of their utilities. If they fail to retain local control and it once passes to the state railroad commission, it cannot be again recovered.

American cities should have greater home rule rights than they now enjoy. The writer believes that the surrender of local control by a large and live municipality would be a misfortune.

\section{Franchises, Permits and Terminals}

The city has generally adopted the policy of short-term grants for franchises limited to twenty-one years with the right of the city to purchase or find a purchaser at the end of five years. Grants for elevated and subway lines may be for forty years with the right to renew for ten years more. The city will have the right to purchase or find a purchaser for the property at the end of the first grant period.

The right to build spur tracks for serving industries, etc., is usually given as a revocable permit, and for a term not to exceed twenty-one years. While the study and design of freight terminals should properly fall within the province of the board, funds have never been available for that purpose. A special commission for the purpose of studying the question has recently been appointed by the council. It is the purpose to bring about, if possible, the unification of all freight terminals with the city, a large if not the dominating and controlling factor. 


\section{The Local Transportation Problem and City Planning}

It is believed without any question that the greatest need of Los Angeles at the present time is for a well worked out comprehensive city plan. The same can be said of most, if not all, American cities. The problem is an immensely bigger one than working out beauty schemes.

Transportation is an absolute necessity for the existence of the modern city. While that is a fact, no more real forethought is given to it, or provision made for properly providing, and taking care of it, than if it were an unheard or undreamed of city need.

The universal tendency is to concentrate the business district on the one hand and more and more expand and extend the residence districts into the outlying sections, on the other. We build a solid mass of sky scrapers, fifteen, twenty, thirty and forty stories high on streets that are no wider than country roads. On leaving the business district we pass by possibly thousands of vacant lots on almost any local transportation line. Every one knows the result, rush hour congestion and long-haul traffic which are now almost hopeless to handle properly and are getting worse every day. What can city planning do to remedy these conditions? A comprehensive plan carried out should undertake to accomplish among other things the following: (1) To limit the height of buildings in the business district to not over six or eight stories, depending on the capacity of the streets, on which they face or into which their occupants find their way, to carry traffic. (2) Encourage and direct the establishment of business and industrial centers outside of the main business center so that large portions of the population can walk to and from their work. Los Angeles is to a degree fortunate in having a hill section lying adjacent to the business district where a large number of its residents can walk to and from their work. On the other hand this same hill, lying as a barrier to the west and north of the business district, restricts and hampers the movement of traffic in and out on the streets available. (3) Control and restrict the laying out of sub-divisions which now goes on beyond any reasonable need or demand; that is, stop the conversion of good agricultural land into poor city property. (4) Adopt a system of taxation that will compel the occupancy and use of what would otherwise remain vacant property. Vacant property as we have it outside the 
business and running through the residence districts is little other than a nuisance, if not worse. It results in a needless amount of improvements, not fully used, the costs of which have to be borne either directly or indirectly, by the community at large. Vacant lots past which sidewalks, pavements, sewers, water and gas mains, electric light and telephone conduits or wires and poles, street railways, etc., are built but not used, are factors of economic waste. In other words the service is spread out thin and the used property has to stand the burden of high costs. It seems only a reasonable proposition that land should not be subdivided until it is needed for use and that after it is laid out it should be used.

It is needless to say that these are only a few of the things that should receive attention for correction. While rush-hour congestion is one of the most aggravating, and we might say hopeless, problems we have to contend with, other improvements and utility service are handicapped and suffer from our lack of forethought and planning.

These are factors that are not as fully and generally recognized as they should be. While we are regulating the utility concerns and undertaking to exact good service at reasonable rates we have left real estate exploitation free to create conditions which impose needless burdens on the community.

\section{New Standards of Civic Patriotism}

The most blighting influence in retarding progress towards ideals is the element of uncontrolled selfishness. We freed ourselves of the tyranny of the inherited "divine right to rule," only to find ourselves all but enslaved by the tyranny of boss rule backed by so-called special privilege and its more vicious allies. Corruption of government and exploitation of the rights and interests of the citizens through those means have been the general experience of American cities.

While the results have been all but disastrous to representative self-government, this feature has not been recognized and condemned by the popular mind, so much as the burden of discrimination, overcharges, and bad service, which they have suffered. Corruption of government by selfish interests has only been a means to an end 
We have been all but too slow in recognizing this influence on the functions of self-government.

If proper regulation will not remove these influences then we will have to undertake the municipal ownership of those activities that are necessary to the municipality and the absolute eradication of those that are not necessary.

With the wonderful initiative and enterprise of the American people the wonder is that we have thus far done so poorly in what should be our greatest work, well planned city building. If we do not build right and on broad lines, regulation of utilities, however done, can go only a small way toward making up deficiencies resulting from our neglect.

The success of the board of public utilities in carrying on an aggressive and constructive program has not been as great as we might have hoped that it should be. With the limitations and handicaps under which it has had to labor the results attained are more than commendable. 